\title{
The Earthly and Sacred in the Semantics of the Tuvinians' Traditional Costume
}

\author{
Maria S. Kukhta ${ }^{a}$, Shenne B. Mainy \\ and Olga M. Khomushku ${ }^{\text {b* }}$ \\ ${ }^{a}$ National Research Tomsk Polytechnic University \\ 30 Lenin, Tomsk, 634050, Russia \\ ${ }^{b}$ Tuvan State University \\ 36 Lenin Str., Kyzyl, Republic Tuva, 667000, Russia
}

Received 02.09.2019, received in revised form 16.10.2019, accepted 11.12.2019

This work is urgent due to the need in studying the Tuvan traditional clothing, which is a part of the "cultural core" of the residents and contributes to the preservation of their national identity. The research aims analyzing the interrelations of the spiritual (sacred) and material (earthly) in the semantics of the Tuvan costume. The subject of the study is the Tuvan folk costume, whereas the main focus is its sign-symbolic nature. The features of the cut, decor and form of the Tuvan costume represent, on the one hand, a unique ethnic specificity, and on the other hand, mean fundamental laws of the Universe inherent in the cultures of all the peoples on the Earth. The study results in the systematization of cultural types of the costume and identification of their symbolic articulation in particular material form (fit, cut or design elements).

Keywords: traditional clothing, the semantics of Tuvan costume, national cut, decor and shape, Tuvan ethnic specificity.

Research area: culturology.

Citation: Kukhta, M.S., Mainy Sh.B., Khomushku, O.M. (2019). The earthly and sacred in the semantics of the tuvinians' traditional costume. J. Sib. Fed. Univ. Humanit. Soc. Sci., 12(12), 2209-2216. DOI: 10.17516/1997-1370-0502.

\section{Introduction}

The current stage of social development is marked with dramatic changes that, in turn, are adjusting the culture of different ethnic groups. The globalizing world determines that traditional cultures are perceived as fundamental support that can

(C) Siberian Federal University. All rights reserved

* Corresponding author E-mail address: eukuh@mail.tomsknet.ru; shenne85@mail.ru; hom17@mail.ru ORCID: 0000-0002-5280-4911 (Khomushku); 0000-0001-8643-785X (Kukhta)

This work is licensed under a Creative Commons Attribution-NonCommercial 4.0 International License (CC BY-NC 4.0). 
resist elimination and unification of cultural values (Khomushku, Kukhta, 2016). An important form of ethnic culture that helps to preserve national cultural identity and build up spiritual ties between generations is traditional costume.

The traditional costume has been the focus for many specialists: e.g. as for the ethnographers, it is associated with ethnic, tribal, social, age; the culturologists regard such clothes as the information about material culture, the semantics of patterns, iconicity of ornaments, influence of other cultures, peoples or tribes; the technologists think that the costume bears the historical value of traditional material processing (linen, wool), weaving methods, dyes and fancywork; the art historians treat the traditional costume mainly as a piece of art created within the common laws of composition, with clear rhythm, colour, proportions, special cut and silhouette. This article sees the traditional costume as a link clarifying the connection between the Tuvan people's material and spiritual culture through a system of signs and symbols expressed in the cuts and decor. This unity of material ("earthly") and spiritual ("sacred") has both a universal nature, reflected in the archetypal patterns of cultures, and a prominent uniqueness of the Tuvan traditional culture.

This study identifies the specifics of the earthly and sacred semantics in the traditional Tuvan costume, which is a unique element of the cultural asset. The authors concern the Tuvan traditional costume its semantics. In the indigenous material culture of Tuvinians, the costume "have a special place ...since, on the one hand, it comes as a part of the material culture, and, on the other, as each of its elements links making techniques, its semantics and design, etc., which are the manifestations of the intangible heritage" (Kimeeva, Ondar, 2016).

\section{Materials and methods}

The study is based on a combination of cultural-historical analysis that reveals the nature of the Tuvinians' national clothing and its types, and structural-semiotic method that allows exploring the features of the sign-symbolic character of the original clothes.

\section{Costume through the mirror of myth}

Tuva's traditional culture is infused with the myth, as far as any mythological representation forms a cultural core and, in Schelling's views, determines its features and patterns of development. Myths are sort of "cultural data", a field of possibilities, a probabilistic lens that one's consciousness throws over the world's chaos (Lobok, 1997). 
The creation of mythologies, myths subjective interpretation and emergence of mythological representations are associated with peoples' life-history and development, with evolution of the cultures and traditions, which do not constitute the basis for allegorical myth-making, but, in turn, are determined by myth. Thus, actions, things, and everyday life, i.e. all that is targeted by the human consciousness in the myth creation times, are the myth. The myth is not necessarily a verbally expressed story: the use of a sound image is absolutely optional for the mythical word to be manifested its plastic mode is ritual and magical practices in all gestures, facial expressions and ritual symbolism.

As noted, the mythological systems of traditional cultures are not the sum of simple knowledge, but a complex holistic worldview that touches upon almost all the fundamental issues that are of peoples' concern up to this day. Myths were a way of understanding the nature and social reality. The essence of the mythological worldview was manifested in humanizing the environment, in animating the cosmos, in aspiration to harmonize the man with the world and the world per se, i.e. to make it alike, and therefore pure and simple. Thus, the traditional cultures have an irreplaceable unity of rituals, magic, economic and manufacturing activities, organically including artistic creation, an integral part of which is the traditional costume.

The Tuvan costume fully expresses the features of mythological consciousness. The mythological cosmology of the ancient Tuvans is characterized by a vertical cosmic model coming from the trichotomous division on heaven, earth and underworld. Thereafter, the costume is a material cover establishing a person-environment contact: the costume encodes ontological information about the person's worldview. Everything related to the human body could be equally interpreted as to the clothes covering that body. The suit modeled the space around the person, made up of the main zones of the Universe: the Upper (heavenly kingdom), the Middle (earth), and the Lower (underground kingdom). Thus, a headdress is associated with the Upper world, outerwear — with the Middle one, and shoes and lower hem symbolizes the Lower.

\section{Functions and types of traditional costume}

The traditional clothing appeared due to its functional need; in addition, it reflected the social and material position, cultural level, and peoples' visions of beauty typical for a particular culture, as well as the persons' gender and age characteristics. The national costume has its symbolism, information value, harmony, forms monumentality, massive elements, original philosophy and language (Norboeva, 2013). 
National clothing appears as a complexity, which includes numerous types of outer and lower clothes, headwear, shoes, jewelry, personal items and hairstyles (Noozun, 2016; Siyanbil, Sinyabil, 2000).

Eight traditional types of the Tuvan clothes are distinguished by the age-sex criterion: children's clothes, girls's costumes, boys's costumes, bride's costumes, women's costumes, men's costumes and costumes for elderly people (Siyanbil, Sinyabil, 2000). The national ton (khalat) of the Tuvinians is determined by the seasons, i.e. winter, spring-autumn and summer (Norboeva, 2013). The clothes also differ by its purpose, i.e. casual, holiday, craft, religious, sports. The types and styles of outerwear for the poor and rich, for children and adults, for men and women are slightly different from each other, so, they usually vary in size, wealth in decor, design and quality of the material. Reality manifestation found in the costume may suggest using certain elements of conventionality and iconicity on the social status coupled with artistic image building (Norboeva, 2013).

Food, housing and costume are those which originally articulate the culture. Being a part of the person's cultural space, the latter reflects changes in the costume's life either at the conceptual or functional level. Thus, in a nomad's costume, as in a system, not only cosmological and religious representations, social stratification, certain artistic traditions, but also the markers of Tuva's cultural contacts with other cultures in the $19^{\text {th }}$ and first half of the $20^{\text {th }}$ centuries are reflected (Nava, 2013).

So, the markers of the Mongolian culture include a wide tunic-like clothes, with the body cut out like a kimono, the right-hand wrap, multi-colored fabric belt, leather shoes with an incurved toe and multi-layer felt outsole. The markers of Chinese culture in the Tuvan costume were found in silk fabrics, in a stepped (Manchu) cut on the left part and in "Manchu" headdresses, as well as in some decor features of traditional clothes (design of khalat's collars), in particular, the Chinese symbols in their decor. The main marker of the Russian culture was a step-by-step elimination of the original system elements from the nomads' costume, and later its replacement with the European model (Russian version), including a change in the hairstyles as well (Nava, 2013).

\section{Sacred semantics of the costume}

The traditional costume of the Tuvinians represents a ritual object marked by a rich sacred semantics. The Tuvan costume is seen not just as a thing, but also as a symbolic sacred form, a sign in the context of culture. Such semantic status of folk clothes was to be read and comprehended both by its owner and by other members of 
the traditional cultural communities, as "a sign (symbol, code, artistic image), made of clothing, shoes, accessories, external behaviours, characteristics of the body and individuality". The costume language is a reflection of the real world, an accumulated spiritual experience of people and practical and aesthetic values given by previous generations.

A traditional costume becomes a symbol, a meaningful sign, which hides a complex motive, image and idea. Such a thought-fertilized sign is always objective and sensual. The symbols represent the unity of the unconscious and conscious, sensual and intelligible, irrational and rational, logical and illogical, incomprehensible and clear. At the same time, the costume can be of a practical use as well (Dubrovina, 2013).

Being a sign communicative system, the costume is made of two core codes types that exist in the general cultural global space, i.e. traditions and fashion. The tradition codes are stable, cyclically invariable and they may bring the information about gender, age, race, ethnicity, cultural, religious preferences, social status, material security and position in the class structure. Such codes refer to a specific area of "ethnic traditional code", which carries the information gained by the generations of ancestors. In this case the costume language is created by the centuries of experience. The ethnic image personifies both the person, people and country together. A key role in the ethnic code formation is played by spatio-temporal, and material and clothing factors, recording the features of the ethnos. The information about an ethnic stereotype, accurately perceived by certain people, presupposes anthropological characteristics of their appearance and behaviour. The traditional costume is not subject to some vivid temporary changes, it symbolizes stability, form permanence, centuries-verified harmony, uncompromising beauty inherent in many generations and narrative. Unlike the tradition codes, the fashion ones, following A.V. Dubrovina, can change and do not have any permanent universal foundation (Dubrovina, 2013).

Each element of the traditional costume had both functional significance and sacred semantics.

In a Tuvan suit, the belt (kur) created practical space behind the bosom (khoyun), where you could keep food during a trip or other necessary things. It requires special respect, as it was a symbol of the protection of all that is hidden, including the holy mother's milk - a drink of life. It also divides the clothes into upper and lower parts (Noozun, 2016).

Khalat (ton) of a married woman differs from the one of a girl by a rounded yoke on the forepart (tonun oruu) and multi-colored cross stripes (bogaa) under. This detail 
symbolizes the "up" - Heaven - Father. The yoke turned into vertical stripes (kydyg) along the bottom of the border. Another peculiarity of the Tuvan khalat were long sleeves (chen) with wrists (ushtuk), dropping below the hands.

In the Turkic languages, the word "edek" refers to the hem, edge of clothing and the mountain foot. The idea of fertility, growth, and earthly interception dominated in the most luxurious khalats of married women (Noozun, 2016).

The idea of closed fixed hems as an ethnographic fact of the wedding ceremony is an important detail: for the married women, the hem is cut out (alangy edek). The edge was clipped, as if opened, horizontally seated and sewn to the hem, creating a rectangular ledge along the left floor, as if opening the way for the future birth. At the cutting line, multi-colored horizontal stripes (shalan) were sewn, invoking new wealth for the family.

The clipped neck on the hem is a symbol of "productive bottom", therefore, "the open hem frees the way for a baby, and closed, movable floors symbolize virginity" (Noozun, 2016).

Thus, the cut forms and elements of the traditional Tuvan costume acquired special semantic significance and translated the unity of the "earthly" and "sacred" worlds in mythological consciousness.

The traditional costume does not illustrate the myth, but, combining mythological symbols in different versions, creates new meanings and new allegories (Kukhta, Mainy, Mongush, 2017; Kukhta, Sokolov, Krauinsh, Bouchard 2017; Mainy, Mongush, 2016). Thus, despite the conservatism of the traditional costume and design (ornaments, decor), it is constantly being changed with new interpretations.

\section{Conclusion}

The traditional Tuvan costume as the most important element of the material culture of the Tuvinians is a "mirror of the myth", which reflects various spheres of life, both material and spiritual. The traditional costume captures the diversity of the whole human life, the complexity of social relations and real human behaviour patterns. The entire costume complex represents an integral system of ordered and interconnected signs and symbols, that help to accumulate, organize and transfer cultural experience.

\section{References}

Dubrovina, A.V. (2013). Kostyum kak znak v kommunikativnoy sisteme obshhestva [Costume as a sign in the communicative system of society]. In Vestnik CHGAKI [Bulletin of ChGAKI], 4, 81-86. 
Kimeeva, T.I., Ondar, A.B. (2016). Traditsionniy kostyum tyurkoyazychnykh narodov Sibiri v sobraniyakh muzeev: istoriya izucheniya i aktualizatsiya [Traditional costume of the Turkic-speaking peoples of Siberia in the collections of museums: the history of study and actualization]. In Vestnik Kazanskogo gosudarstvennogo universiteta kul'tury i iskusstv [Bulletin of Kazan State University of Culture and Arts], $2,25-27$.

Kukhta, M.S., Mainy, Sh.B., Mongush, Ch. Kh. (2017). Kul’turnaya semantika ehtno-dizaina traditsionnykh ukrasheniy Tuvy [Cultural semantics of ethno-design of traditional jewelry of Tuva]. In Uspekhi sovremennoj nauki i obrazovaniya [The Success of Modern Science and Education], 4, 92-95.

Kukhta M. S. , Sokolov A. P. , Krauinsh D. P. , Bouchard C. K. (2017) Stylization levels of industrial design objects. Journal of Physics: Conference Series. 2017. Vol. 803, Article number 012082. p. 1-5

Lobok, A.M. (1997). Antropologiya mifa [Anthropology of Myth]. Yekaterinburg, $688 \mathrm{p}$.

Mainy, Sh.B., Mongush, M.M. (2016). Tuvinskie zhenskie ukrasheniya [The Tuvan women's jewelries]. In Materialy IV mezhdunarodnoy nauchno-prakticheskoy konferentsii molodykh uchenykh, aspirantov i studentov "Aktual'nye problemy issledovaniya ehtnoehkologicheskikh i ehtnokul'turnykh traditsiy narodov Sayano-Altaya" [The Proceedings of the $4^{\text {th }}$ International Scientific and Practical Conference of Young Scientists, Post-Graduates and Students “Topical problems of research of ethnoecological and ethno-cultural traditions of the peoples of the Sayano-Altai'”, 44-55.

Nava, S.S. (2013). Kochevaya kul 'tura tuvintse skvoz' prizmu kul 'turnykh kontaktov: kul'turologicheskoe issledovanie [The Nomadic culture of the Tuvinians through the lens of cultural contacts: cultural studies]. Irkutsk, Ottisk, 132 p.

Noozun, O. Kh. (2016). Tuvinskoe dekorativno-prikladnoe iskusstvo: vekhi istoriko-kul'turnogo razvitiya [Tuvan decorative and applied art: landmarks of historical and cultural development]. Kyzyl, Tyvapoligraf, 153 p.

Norboeva, T.B. (2013). Etnicheskiy kostyum buryat: traditsii i sovremennost' [The ethnic costume of Buryats: traditions and modernity]. In Ojkumena. Regionovedcheskie issledovaniya [Oecumene. Regional studies], 1, 108-114.

Siyanbil, M., Sinyabil, A. (2000). Traditsionniy tuvinskiy kostyum (Istoriya. Simvolika) [The traditional Tuvan costume (History. Symbolism)]. Kyzyl, 72 p.

Khomushku, O.M., Kukhta, M.S. (2016). Etnokonfessional'niy faktor v dukhovnom vozrozhdenii Tuvy: sotsial'no-filosofskij analiz [Ethno-confessional factor 
in the spiritual revival of Tuva: socio-philosophical analysis]. In Vestnik Kalmytskogo instituta gumanitarnykh issledovaniy RAN [Bulletin of Kalmyk Humanitarian Research Institute of the Russian Academy of Sciences], 5, 119-126.

Khomushku, O.M., Sanchay, Ch. Kh., Kukhta, M.S. (2019). Archetypical symbols in the modern Tuvan culture. In Journal of Siberian Federal University. Humanities and Social Science, 12(7), 1132-1145. DOI: 10.17516/1997-1370-0445

\title{
Земное и сакральное в семантике традиционного костюма тувинцев
}

\author{
М.С. Кухта ${ }^{a}$ Ш.Б. Майны ${ }^{\sigma}$, О.М. Хомушкуб \\ ${ }^{a}$ Национальный исследовательский \\ Томский политехнический университет \\ Россия, 634050, Томск, пр. Ленина, 30 \\ ${ }^{6}$ Тувинский государственный университет \\ Россия, 667000, Республика Тыва, Кызыл, ул. Ленина, 36
}

Актуальность работы связана с необходимостью изучения традиционной одежды тувинцев, входящей в «культурное ядро» тувинского народа и способствующей сохранению его начионального своеобразия. Целью работы стало исследование взаимосвязей духовного (сакрального) и материального (земного) в семантике тувинского костюма. Объектом исследования выступает тувинский народный костюм, предметом знаково-символическая природа традиционного костюма тувинцев. Особенности кроя, декора и формы тувинского костюма, с одной стороны, являются яркой уникальной этнической спецификой, а с другой - несут универсальные законы Мироздания, присущие культурам всех народов Земли. Результать исследования представляют собой систематизацию культурных видов костюма и выявление их символического звучания в конкретном материальном выражении (форме, крое, элементах декора).

Ключевые слова: традиционная одежда, семантика тувинского костюма, национальный крой, декор и форма, тувинская этническая специфика.

Научное направление: 24.00.00 - культурология. 